\title{
ANALISA KERUSAKAN JALAN PADA RUAS JALAN RAYA JAKARTA KM. 04 KOTA SERANG MENGGUNAKAN METODE PCI PAVEMENT CONDITION INDEX) DAN SDI (SURFACE DISTRESS INDEX) DAN ALTERNATIF PENANGANANNYA
}

\author{
${ }^{1}$ Nila Prasetyo Artiwi, ${ }^{2}$ Euis Amilia, ${ }^{3}$ Herga Jaya Abadi \\ ${ }^{3}$ Program Studi Teknik Sipil, Universitas Banten Jaya, Jl. Raya Ciwaru II No. 73 Kota Serang Banten \\ Email: prasetyonila2@gmail.com
}

\begin{abstract}
ABSTRAK
Ruas Jalan Raya Jakarta Km. 04 Kota Serang adalah salah satu bagian dari ruas jalan Provinsi (menurut statusnya) dan jalan kolektor menurut fungsinya. Jalan ini memiliki perkerasan lentur dengan lebar $14 \mathrm{~m}$ dan tidak memiliki bahu jalan maupun median. Kendaraan yang melewati jalan tersebut setiap harinya sangat ramai, sehingga kerusakan permukaan jalan yang ada akan mempengaruhi keamanan, kelancaran, dan kenyamanan bagi pengguna jalan tersebut. Penelitian ini dilakukan untuk mengetahui nilai kondisi permukaan jalan raya Jakarta Km. 04 Kota Serang. Metode yang digunakan untuk penelitian yaitu metode PCI (Pavement Condition Index) dan Metode SDI (Surface Distress Index) beserta alternatif penanganannya. Berdasarkan hasil penelitian yang dilakukan menurut metode PCI (Pavement Condition Index) yaitu pada STA 0+000 s.d 2+000 terdapat 9 jenis kerusakan dengan persentase berbeda-beda dan hasil nilai PCI rata-rata yaitu sebesar 44.75 dan masuk dalam kategori Sedang (Fair) sedangkan dengan menggunakan metode SDI (Surface Distress Index)pada STA 0+000 s.d 2+000 didapatkan hasil SDI rata-rata yaitu sebesar 54.75 dan termasuk dalam kategori Sedang.
\end{abstract}

Kata Kunci : Metode PCI (Pavement Condition Index), Metode SDI (Surface Distress Index), Nilai kerusakan jalan

\begin{abstract}
Jakarta highway Km. 04 Serang City is one part of the Provincial road segment according to status and collector road according to function. This road has a width of $14 \mathrm{~m}$ and has no shoulder and median. Number of vehicles passing the road. For the sake of safety that will increase security, smoothness, and comfort for road users. This research was conducted to determine the value of the Jakarta highway conditions Km. 04 City of Serang. The method used for this research is the PCI (Pavement Condition Index) method and the SDI (Surface Distress Index) method and also the treatment. Based on the results of research conducted based on the method of PCI (Pavement Condition Index), namely the STA $0+000$ to $2+000$ based on 9 types of damage with different differences and the average PCI value of 44.75 and included in the Medium category (Fair), while using the SDI (Surface Distress Index) method on STA $0+$ 000 to $2+000$, the average SDI results are 54.75 and included in the Medium category.

Key Word: PCI (Pavement Condition Index) Method, SDI (Surface Distress Index) Method, Road damage value
\end{abstract}

\section{PENDAHULUAN}

Berdasarkan peraturan Menteri Pekerjaan Umum Republik Indonesia No: 03/PRT/M/2012 tentang pedoman penetapan fungsi jalan dan status jalan, jalan merupakan suatu prasarana perhubungan darat dalam bentuk apapun meliputi segala bagian jalan termasuk bangunan pelengkap dan perlengkapannya yang diperuntukkan bagi lalu lintas. Peranan jalan sebagai prasarana transportasi sangat vital bagi kemajuan suatu wilayah. Kondisi jalan yang dapat dilalui oleh kendaraan dengan aman dan nyaman adalah yang memiliki perkerasan yang baik, terdiri dari campuran agregat dan bahan pengikat yang telah melalui tahapan uji mutu bahan di laboratorium. Perkerasan jalan terdiri atas perkerasan lentur (flexible pavement) dan perkerasan kaku (rigid pavement). 
Ruas Jalan Raya Jakarta Km. 04 Kota Serang adalah salah satu bagian dari ruas jalan Provinsi (menurut statusnya) dan jalan kolektor menurut fungsinya. Jalan ini memiliki perkerasan lentur dengan lebar $14 \mathrm{~m}$ dan tidak memiliki bahu jalan maupun median. Banyaknya kendaraan besar seperti truk pengangkut tanah, pasir serta bus penumpang menuju Kabupaten Serang serta kondisi jalan yang sudah mengalami banyak kerusakan tentu saja mengurangi tingkat pelayanan jalan. Dengan adanya kondisi ini , maka perlu dilakukan investigasi dan penilaian terhadap jenis-jenis (bentuk) kerusakan dan seberapa besar tingkat kerusakan pada jalan tersebut. Sehingga perlu dilakukan survey kerusakan jalan menggunakan metode PCI (Pavement Condition Index) dan SDI (Surface Distress Index) agar dapat mengetahui nilai kondisi pada perkerasan jalan tersebut secara visual. Adapun perbedaan antara kedua metode diatas yaitu pada metode Surface Distress Index penentuan nilai kondisi jalan dilakukan dengan menjumlahkan setiap angka dan nilai untuk masing-masing keadaan kerusakan. Pada metode Pavement Condition Index (PCI) perhitungannya didasarkan atas hasil survei kondisi jalan secara visual yang teridentifikasi dari tipe kerusakan, tingkat kerusakan (severity), dan kuantitasnya.

Penelitian ini bertujuan untuk mengetahui jenis dan tingkat kerusakan yang terjadi pada ruas jalan raya Jakarta Km.4 Kota serang sepanjang 2000 meter menggunakan 2 metode yaitu metode PCI (Pavement Condition Index) dan SDI (Surface Distress Index) dan mengetahui bagaimana pemeliharaan yang dilakukan untuk kerusakan yang terjadi pada ruas jalan yang diteliti.

\section{TINJAUAN PUSTAKA}

Perkerasan Jalan Perkerasan jalan adalah bagian konstruksi jalan yang terdiri dari beberapa susunan atau lapisan, terletak pada suatu landasan atau tanah dasar yang diperuntukkan bagi jalur lalu lintas dan harus cukup kuat untuk memenuhi dua syarat utama sebagai berikut :

1. Syarat berlalu lintas seperti permukaan jalan tidak bergelombang, tidak melendut, berlubang, cukup kaku, dan tidak mengkilap. Selain itu jalan harus dapat menahan gaya gesekan atau keausan terhadap roda-roda kendaraan.

2. Syarat kekuatan/struktural yang secara keseluruhan perkerasan jalan harus cukup kuat untuk memikul dan menyebarkan beban lalu lintas yang melintas diatasnya. Selain itu harus kedap air, permukaan mudah mengalirkan air serta mempunyai ketebalan cukup.

Silvia sukirman (1999) menyatakan bahwa : Lapis perkerasan lentur (flexible pavement) adalah lapis perkerasan yang menggunakan aspal sebagai bahan ikat antar material.

Penilaian kondisi kerusakan perkerasan yang dikembangkan oleh U.S. Army Corp of Engineer (Shahin et al., 1976-1984), dinyatakan dalam Indeks Kondisi Perkerasan (Pavement Condition Index,PCI). Metode PCI memberikan informasi kondisi perkerasan hanya pada saat survey dilakukan, tapi tidak dapat memberikan gambaran prediksi dimasa datang.Namun demikian, dengan melakukan survey kondisi secara periodik, informasi kondisi perkerasan dapat berguna untuk prediksi kinerja dimasa datang, selain juga dapat digunakan sebagai masukan pengukuran yang lebih detail.

Tabel 1. Besaran Nilai PCI

\begin{tabular}{cll}
\cline { 2 - 2 } Nilai PCI & Kondisi Jalan \\
\hline $85-100$ & Sempurna (excellent) \\
$70-84$ & Saat Baik (very good) \\
$55-69$ & Baik (good) \\
$40-54$ & Sedang (fair) \\
$25-39$ & Buruk (poor) \\
$10-24$ & Sangat Buruk (very poor) \\
$0-10$ & Gagal (failed)
\end{tabular}

Sumber : Hardiyatmo, 2007 
PCI adalah tingkatan dari kondisi permukaan perkerasan dan ukuran yang ditinjau dari fungsi daya guna yang mengacu pada kondisi dan kerusakan dipermukaan perkerasan yang terjadi.PCI ini merupakan indeks numerik yang nilainya berkisar di antara 0 sampai 100. PCI dikembangkan untuk memberikan indeks dari integritas struktur perkerasan dan kondisi operasional permukaannya. Informasi kerusakan yang diperoleh sebagai bagian dari survey kondisi PCI, memberikan informasi sebab-sebab kerusakan, dan apakah kerusakan terkait dengan beban atau iklim. Dalam metode PCI, tingkat keparahan kerusakan perkerasan terdiri atas tiga indicator, yaitu : tipe kerusakan ,tingkat keparahan kerusakan serta jumlah atau kerapatan kerusakan.

Dalam hitungan PCI, maka terdapat istilah-istilah sebagai berikut ini, Nilai Pengurang (Deduct Value) merupakan nilai pengurang untuk setiap jenis kerusakan yang diperoleh dari kurva hubungan kerapatan (density) dan tingkat keparahan (severity level) kerusakan.Karena banyaknya kemungkinan kondisi perkerasan, untuk menghasilkan satu indeks yang memperhitungkan ketiga faktor tersebut umumnya menjadi masalah. Untuk mengatasi hal ini, nilai pengurang dipakai sebagai tipe faktor pemberat yang mengindikasikan derajat pengaruh kombinasi tiap-tiap tipe kerusakan, tingkat keparahan kerusakan, dan kerapatannya. Untuk menentukan PCI dari bagian perkerasan tertentu, maka bagian tersebut dibagi-bagi kedalam unit-unit inspeksi yang disebut unit sampel. Kerapatan adalah persentase luas atau panjang total dari satu jenis kerusakan terhadap luas atau panjang total bagian jalan yang diukur. Nilai pengurang total atau TDV adalah jumlah total dari nilai pengurang (Deduct Value) pada masing-masing unit sampel. Nilai Pengurang Terkoreksi (Corrected Deduct Value, CDV) diperoleh dari kurva hubungan antara nilai pengurang total (TDV) dan nilai pengurang (DV) dengan memilih kurva yang sesuai. Jika nilai CDV yang diperoleh lebih kecil dari nilai pengurang tertinggi (Highest Deduct Value, HDV), maka CDV yang digunakan adalah nilai pengurang individual yang tertinggi. Nilai PCI untuk setiap unit sampel dihitung dengan menggunakan persamaan :

PCIs $=100-$ CDV, dimana PCIs adalah PCI untuk setiap unit segmen atau unit penelitian. Menurut Metode Pavement Condition Index (PCI), jenis dan tingkat kerusakan perkerasan lentur jalan raya dibedakan menjadi (Hary Christad, 2015) :

a. Retak Kulit Buaya (Aligator Cracking), berupa retak yang berbentuk sebuah jaringan dari bidang persegi banyak (polygon) kecil menyerupai kulit buaya, dengan lebar celah lebih besar atau sama dengan $3 \mathrm{~mm}$. Retak ini disebabkan oleh kelelahan akibat beban lalu lintas yang berulang-ulang.

b. Kegemukan (Bleeding), cacat permukaan ini berupa terjadinya konsentrasi aspal pada suatu tempat tertentu di permukaan jalan. Bentuk fisik dari kerusakan ini dapat dikenali dengan terlihatnya lapisan tipis aspal (tanpa agregat) pada permukaan perkerasan dan jika pada kondisi temperatur permukaan perkerasan yang tinggi (terik matahari) atau pada lalu lintas yang berat, akan terlihat jejak bekas 'bunga ban' kendaraan yang melewatinya. Hal ini juga akan membahayakan keselamatan lalu lintas karena jalan akan menjadi licin.

c. Retak Kotak-kotak (Block Cracking), retak ini berbentuk blok atau kotak pada perkerasan jalan. Retak ini terjadi umumnya pada lapisan tambahan (overlay), yang menggambarkan pola retakan perkerasan di bawahnya. Ukuran blok umumnya lebih dari $200 \mathrm{~mm}$ x $200 \mathrm{~mm}$.

d. Cekungan (Bumb and Sags)

e. Keriting (Corrugation) Kerusakan ini dikenal juga dengan istilah lain yaitu, Ripples. Bentuk kerusakan ini berupa gelombang pada lapis permukaan, atau dapat dikatakan alur yang arahnya melintang jalan, dan sering disebut juga dengan Plastic Movement.

f. Amblas (Depression). Bentuk kerusakan yang terjadi ini berupa amblas atau turunnya permukaan lapisan permukaan perkerasan pada lokasi-lokasi tertentu (setempat) dengan atau tanpa retak. Kedalaman kerusakan ini umumnya lebih dari $2 \mathrm{~cm}$ dan akan

g. menampung atau meresapkan air.

h. Retak Tepi (Edge Cracking). Retak pinggir adalah retak yang sejajar dengan jalur lalu lintas dan juga biasanya berukuran 1 sampai 2 kaki $(0,3-0,6 \mathrm{~m})$ dari pinggir perkerasan. Ini biasa disebabkan oleh beban lalu lintas atau cuaca yang memperlemah pondasi atas maupun pondasi bawah yang dekat dengan pinggir perkerasan.

i. Retak Sambung (Joint Reflec Cracking). Kerusakan ini umumnya terjadi pada perkerasan aspal yang telah dihamparkan di atas perkerasan beton semen portland. Retak terjadi 
j. pada lapis tambahan (overlay) aspal yang mencerminkan pola retak dalam perkerasan beton lama yang berbeda di bawahnya.

k. Retak Memanjang / Melintang (Longitudinal / Trasverse Cracking) Jenis kerusakan ini terdiri dari macam kerusakan sesuai dengan namanya yaitu, retak memanjang dan melintang pada perkerasan. Retak ini terjadi berjajar yang terdiri dari beberapa celah.

1. Tambalan (Patching end Utiliti Cut Patching). Tambalan adalah suatu bidang pada perkerasan dengan tujuan untuk mengembalikan perkerasan yang rusak dengan material yang baru untuk memperbaiki perkerasan yang ada. Tambalan adalah pertimbangan kerusakan diganti dengan bahan yang baru dan lebih bagus untuk perbaikan dari perkerasan sebelumnya.

m. Pengausan Agregat (Polised Agregat). Kerusakan ini disebabkan oleh penerapan lalu lintas yang berulang-ulang dimana agregat pada perkerasan menjadi licin dan perekatan dengan permukaan roda pada tekstur perkerasan yang mendistribusikannya tidak sempurna.

n. Lubang (Pothole). Kerusakan ini berbentuk seperti mangkok yang dapat menampung dan meresapkan air pada badan jalan. Kerusakan ini terkadang terjadi di dekat retakan, atau di daerah yang drainasenya kurang baik (sehingga perkerasan tergenang oleh air).

o. Alur (Rutting). Istilah lain yang digunakan untuk menyebutkan jenis kerusakan ini adalah longitudinal ruts, atau channel/rutting. Bentuk kerusakan ini terjadi pada lintasan roda sejajar dengan asjalan dan berbentuk alur.

p. Pelepasan Butir (Weathering / Raveling). Pelepasan butiran disebabkan lapisan perkerasan yang kehilangan aspal atau tar pengikat dan tercabutnya partikel-partikel agregat. Kerusakan ini menunjukan salah satu pada aspal pengikat tidak kuat untuk menahan gaya dorong roda kendaraan atau presentasi kualitas campuran jelek.

q. Sungkur (Shoving). Sungkur adalah perpindahan lapisan perkerasan pada bagian tertentu yang disebabkan oleh beban lalu lintas. Beban lalu lintas akan mendorong berlawanan dengan perkerasan dan akan menghasilkan ombak pada lapisan perkerasan.

SDI (Surface Distress Index) merupakan sistem penilaian kondisi perkerasan jalan berdasarkan dengan pengamatan visual dan dapat digunakan sebagai acuan dalam usaha pemeliharaan. Dalam pelaksanaan metode SDI dilapangan maka ruas jalan yang akan disurvei harus dibagi ke dalam segmen-segmen.

Tabel 2.Penilaian Nilai SDI Luas Retak

\begin{tabular}{ccc}
\hline Angka & Kategori Luas Retak & Nilai SDI $_{\mathbf{a}}$ \\
\hline $\mathbf{1}$ & Tidak Ada & - \\
$\mathbf{2}$ & $<10 \%$ & 5 \\
$\mathbf{3}$ & $10 \%-30 \%$ & 20 \\
$\mathbf{4}$ & $>30 \%$ & 40 \\
\hline
\end{tabular}

Sumber : Bina Marga, 2011

Tabel 3.Penilaian Nilai SDI Lebar Retak

\begin{tabular}{ccc}
\hline Angka & Kategori Lebar Retak & Nilai SDI $_{\mathbf{b}}$ \\
\hline $\mathbf{1}$ & Tidak Ada & - \\
$\mathbf{2}$ & Halus $<1 \mathrm{~mm}$ & - \\
$\mathbf{3}$ & Sedang $1-3 \mathrm{~mm}$ & - \\
$\mathbf{4}$ & Lebar $>3 \mathrm{~mm}$ & Hasil SDI $_{\mathrm{a}} \times 2$ \\
\hline Sumber : Bina Marga, 2011 & &
\end{tabular}


Tabel 4.Penilaian Nilai SDI Jumlah Lubang

\begin{tabular}{ccc}
\hline Angka & Kategori Jumlah Lubang & Nilai SDI $_{\mathbf{c}}$ \\
\hline $\mathbf{1}$ & Tidak Ada & - \\
$\mathbf{2}$ & $<10 / 100 \mathrm{~m}$ & Hasil SDI $_{\mathrm{b}}+15$ \\
$\mathbf{3}$ & $10-50 / 100 \mathrm{~m}$ & ${\text { Hasil } \mathrm{SDI}_{\mathrm{b}}+75}$ \\
$\mathbf{4}$ & $>50 / 100 \mathrm{~m}$ & Hasil SDI $_{\mathrm{b}}+225$ \\
\hline
\end{tabular}

Sumber : Bina Marga, 2011

Tabel 5.Penilaian Nilai SDI Bekas Roda

\begin{tabular}{cccc}
\hline Angka & Kategori Bekas Roda & Nilai X & Nilai SDI \\
\hline $\mathbf{1}$ & Tidak Ada & - & - \\
$\mathbf{2}$ & $<1$ cm dalam & 0,5 & Hasil SDI $_{c}+5 \times 0,5$ \\
$\mathbf{3}$ & $1-3$ dalam & 2 & ${\text { Hasil } \mathrm{SDI}_{\mathrm{c}}+5 \times 2}$ \\
$\mathbf{4}$ & $>3 \mathrm{~cm}$ dalam & 4 & Hasil SDI $_{\mathrm{c}}+5 \times 4$ \\
\hline
\end{tabular}

Sumber : Bina Marga, 2011

Penelitian terdahulu dilakukan oleh Ari Sanjaya, Yudi, dkk, dengan Judul Evaluasi tingkat kerusakan permukaan jalan untuk menentukan jenis perancangan dengan sistem penilaian menurut Surface Distress Index (Studi Kasus Jalan Nasional Bireuen-Bts. Kota Lhokseumawe, Kecamatan Krueng Geukueh mulai Sta 253+000 s/d Sta 257+000). Lhokseumawe terbit pada Jurnal Teknik Sipil Sains Terapan - Politeknik Negeri Lhokseumawe yang menyimpulkan bahwa nilai IRI rata-rata persegmen yang adalah pada segmen I 3,30 $\mathrm{m} / \mathrm{km}$, segmen II 4,03 m/km, segmen III 5,47 m/km, segmen IV 3,84 m/km. Sedangkan berdasarkan penilaian SDI didapat untuk jenis kerusakan permukaan jalan yaitu retak (crack) 34,445\%; tambalan (patching) 65,102\%; ambles (depression) 0\%; lubang (potholes) 0,381\%; dan pinggir pecah (edge breaks) 0,071\%. Tingkat kerusakan permukaan jalan keseluruhan dari beberapa jenis kerusakan adalah $4,198 \%$ dari total panjang jalan yang ditinjau sepanjang $4 \mathrm{~km}$. Hasil kondisi tingkat kerusakan jalan yang ditinjau yaitu 55,00\% baik; 24,00\% sedang; 5\% rusak ringan; dan 0\% rusak berat, maka penentuan jenis penanganan jalan dari 4 (empat) segmen seperti segmen I, II, III, dan IV yaitu pemeliharaan rutin. Selanjutnya adalah Baihaqi dkk dengan Judul Tinjauan Kondisi Perkerasan Jalan Dengan Kombinasi Nilai International Roughness Index (IRI) dan Surface Distress Index(SDI) Pada Jalan Takengon - Blangkejeren, Banda Aceh yang diterbitkan dalam Jurnal Teknik sipil - Universitas Syiah Kuala, 2018 dengan hasil penelitian menunjukkan tingkat kerusakan keseluruhan permukaan jalan adalah sebesar 30,54\% sedangkan permukaan jalan yang tidak mengalami kerusakan sebesar $69,46 \%$ dari total panjang jalan yang menjadi objek penelitian, yaitu 12,63 Km yang dibagi menjadi 6 buah segmen jalan. Untuk kondisi keseluruhan jalan yang ditinjau 45,02\% baik, 45,81\% sedang, 6,87 \% rusak ringan, 2,29\% rusak berat. ; serta Yahya, Rafiko, dkk dengan judul Analisa kerusakan Jalan menggunakan Metode Pavement Condition Iindex (PCI) dan Surface Condition Index (SDI), Malang yang terbit dalam Conference on Innovation and Application of Science and Technology (CIASTECH 2019) Universitas Widyagama Malang, 02 Oktober 2019. Hasil penelitian menunjukkan nilai kerusakan permukaan jalan berdasarkan metode Pavement Condition Index (PCI) yaitu Good $12.7 \%$, satisfactory $10.7 \%$, fair 33.3 $\%$, poor $20.7 \%$, very poor $15.3 \%$, serious $6 \%$ dan failed $1.3 \%$. Dengan perhitungan menggunakan metode Pavemanet Index Condition (PCI), didapat nilai rata - rata PCI sebesar 56,89 menunjukkan kondisi permukaan jalan dalam kondisi Fair. Pada penilaian kondisi permukaan jalan dengan metode Surface Distress Index (SDI) nilai kerusakan permukaan jalan yang terjadi yaitu Baik $61 \%$, sedang $16 \%$, rusak ringan $0 \%$, dan rusak berat $23 \%$.

\section{METODOLOGI PENELITIAN}

Penelitian ini dilakukan dengan teknik pengambilan data langsung dari lapangan untuk mendapatkan dimensi serta jenis kerusakan yang ada, Data yang diperoleh dari survey kerusakan jalan dianalisa menggunakan metode PCI (Pavement Condition Index) dan SDI (Surface Distress Index). Data sekunder berupa data jurnal penelitian tentang kerusakan jalan raya, serta dokumen tentang jalan dari Surface Distress Index. Adapun diagram alur penelitian adalah sebagai berikut : 


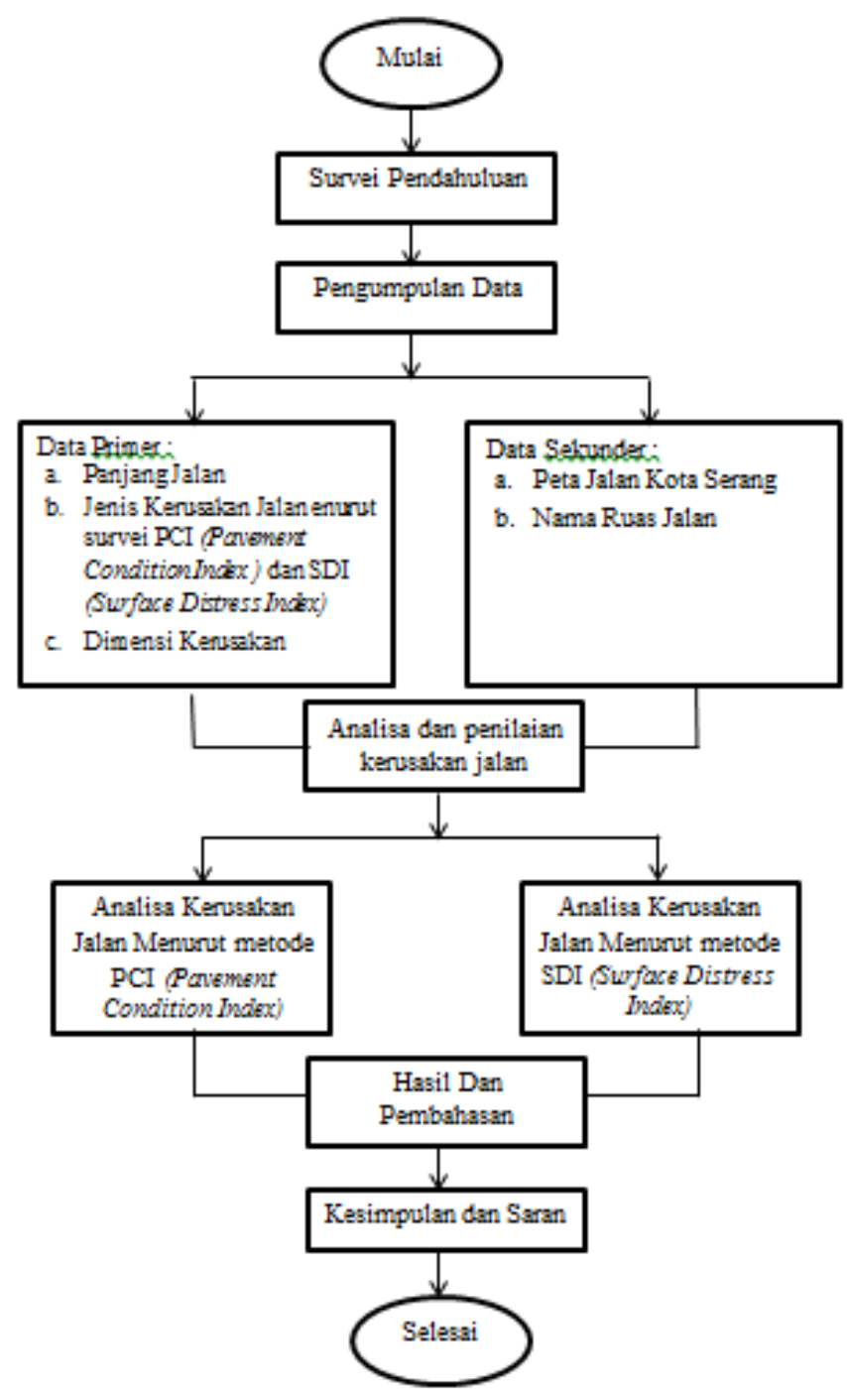

Gambar 1. Alur diagram penelitian

\section{DATA DAN ANALISA}

Analisa data kerusakan pada ruas Jalan Raya Jakarta Km.4 Kota Serang, Banten sepanjang 2000 meter yang dilakukan melalui survey kondisi permukaan jalan yang dilakukan secara visual yang dibantu dengan peralatan untuk pengukuran. Ruas jalan dibagi menjadi 20 segmen dan setiap segmen panjangnya 100 meter. Analisa kerusakan jalan menggunakan 2 metode yaitu metode metode PCI (Pavement Condition Index) dan SDI (Surface Distress Index). Langkah -langkahnya sebagai berikut :

A. Metode PCI (Pavement Condition Index)

1. Membuat Tabel Survei Kerusakan Jalan 
Tabel 6. Data kondisi dan Hasil Pengukuran Ruas Jalan Raya

Jakarta Km.4 Kota Serang

\begin{tabular}{|c|c|c|c|c|c|}
\hline \multicolumn{6}{|c|}{ Nama Survey : Survei Kondisi Kerusakan Jalan } \\
\hline Lokasi & \multicolumn{5}{|c|}{ : Ruas Jalan Raya Jakarta Km.4 Kota Serang } \\
\hline Cuaca & \multirow{2}{*}{\multicolumn{2}{|c|}{$\begin{array}{l}: \text { Cerah } \\
: \text { Team }\end{array}$}} & \multicolumn{2}{|c|}{ Panjang } & \multirow{2}{*}{$\begin{array}{l}: 2000 \mathrm{~m} \\
: 7 \mathrm{~m}\end{array}$} \\
\hline Surveyor & & & & & \\
\hline \multirow{2}{*}{ STA. } & \multirow{2}{*}{$\begin{array}{c}\text { Kelas } \\
\text { Kerusakan }\end{array}$} & \multicolumn{3}{|c|}{ Ukuran } & \multirow{2}{*}{ Jenis Kerusakan } \\
\hline & & $\mathbf{P}(\mathbf{m})$ & $\mathbf{L}(\mathbf{m})$ & h (m) & \\
\hline $0+000-$ & $\mathrm{L}$ & 0.3 & 0.5 & 0.02 & Lubang \\
\hline \multirow[t]{8}{*}{$0+100$} & $\mathrm{H}$ & 1.2 & 1.6 & 0.03 & Lubang \\
\hline & $\mathrm{L}$ & 4 & 0.7 & & Retak Pinggir \\
\hline & $\mathrm{L}$ & 5 & 0.3 & & Retak Pinggir \\
\hline & M & 3 & 1.2 & & Retak Kulit Buaya \\
\hline & M & 1 & 0.5 & & Kegemukan \\
\hline & M & 2 & 0.8 & & Kegemukan \\
\hline & M & 6.1 & 2.2 & 0.04 & Amblas \\
\hline & & 3.8 & 2.1 & 0.04 & Amblas \\
\hline
\end{tabular}

Sumber : Survey, 2020

2. Membagi menjadi beberapa segmen berjarak 100 meter, memasukan jenis dan tingkat kerusakan serta jumlah titik dan luasan kerusakan pada tiap jarak 100 meter per segmen dari total panjang 2000 meter. Dari pembagian persegmen, didapat totalnya yaitu 20 segmen pada Ruas Jalan Raya Jakarta Km.4 Kota Serang.

3. Menentukan Nilai Quantity

a. Menjumlahkan luas atau jumlah unit kerusakan pada setiap tingkat kerusakan yang diamati, lalu masukan di kolom "Total", contoh pada STA 0+100 s.d 0+100 sebagai berikut :

Lubang $(\mathrm{L}) \quad=0.15 \mathrm{~m}^{2}$

b. Menghitung Kerapatan (density)

Menghitung density menggunakan rumus berikut :

Density $\%=\frac{A s}{A d} \times 100 \%$ atau Density $\%=\frac{L d}{A d} \times 100 \%$

Keterangan :

$\mathrm{Ad}=$ Luas total jenis kerusakan untuk tiap tingkat kerusakan $\left(\mathrm{m}^{2}\right)$

$\mathrm{Ld}=$ Panjang total jenis kerusakan untuk tiap tingkat kerusakan $(\mathrm{m})$

As $=$ Luas Total unit $\left(\mathrm{m}^{2}\right)$

Lubang $(\mathrm{L})=\frac{0.15}{700} \times 100 \%=0.021 \%$

c. Mencari nilai pengurangan (deduct value)

Deduct Value (DV) didapat dari grafik jenis-jenis kerusakan. Adapun cara unuk menentukan DV yaitu dengan memasukan persen density pada masing masing grafik jenis kerusakan lalu tarik garis vertical sampai memotong tingkat kerusakan (low, medium, high), selanjutnya pada titik potong tersebut ditarik garis horizontal dan akan didapat nilai Deduct Value. Contoh mencari DV pada STA 0+000 s.d 0+100 sebagai berikut :

$\begin{array}{ll}\text { Lubang } & =0.021 \% \\ \text { Kelas Kerusakan } & =\operatorname{Low}(\mathrm{L}) \backslash \\ \text { Deduct Value } & =6\end{array}$




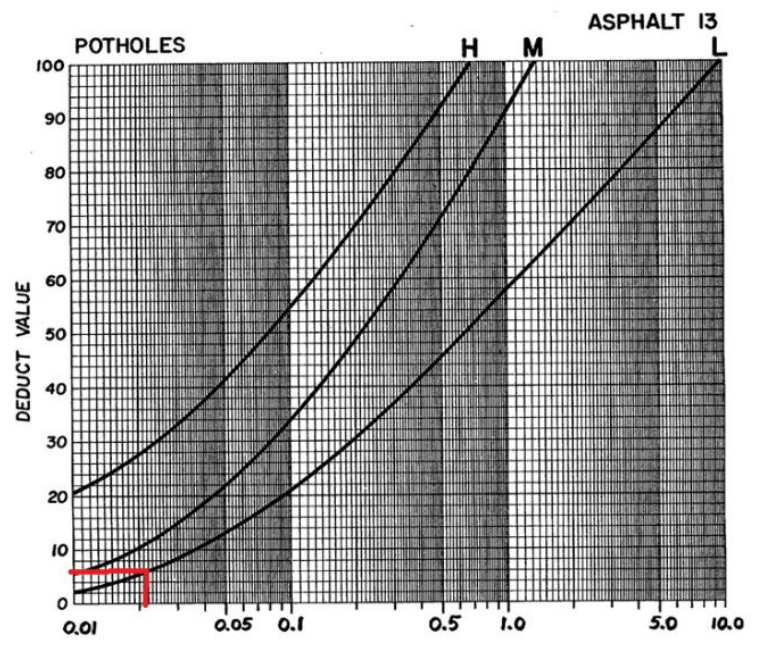

Gambar 2. Grafik Deduct Value Lubang

Sumber : Hasil Analisis, 2020

d. Menjumlah Total Deduct Value

Nilai pengurangan total atau $T D V$ adalah jumlah total dari nilai-nilai pengurangan (deduct value) pada masing masing sampel . Contoh untuk STA 0+000 s.d 0+100 diperoleh Total Deduct Value yaitu sebesar 121.

e. Mencari nilai $\mathrm{q}$

Nilai q didapat dari banyaknya nilai Deduct Value yang lebih besar dari 2 untuk perkerasan dengan permukaan aspal. Pada STA 0+000 s.d 0+100 terdapat 6 nilai Deduct Value tetapi yang lebih besar dari 2 ada 4 nilai, maka nilai q diambil 4.

Tabel 7. Perhitungan CDV

\begin{tabular}{cccccccccccc}
\hline STA & \multicolumn{1}{c}{ Deduct Value (DV) } & & Total & q & CDV & $\begin{array}{c}\text { 100- } \\
\text { CDV }\end{array}$ & PCI \\
\hline $\begin{array}{c}0+000 \\
- \\
0+100\end{array}$ & 6 & 78 & 2 & 16 & 1 & 14 & 117 & 4 & 67 & 33 & Poor \\
\hline
\end{tabular}

f. $\quad$ Menentukan Corrected Deduct Value (CDV)

Setelah didapatkan niali q, lalu nilai CDV dapat didapat dengan cara memasukan nilai TDV pada brafik lalu menarik garis vertical sampai memotong garis q kemudian tarikj garis horizontal untuk mendapatkan nilai CDV. Dari grafik dibawah didapatkan niali CDV untuk STA 0+000 s.d 0+100 sebesar 67.

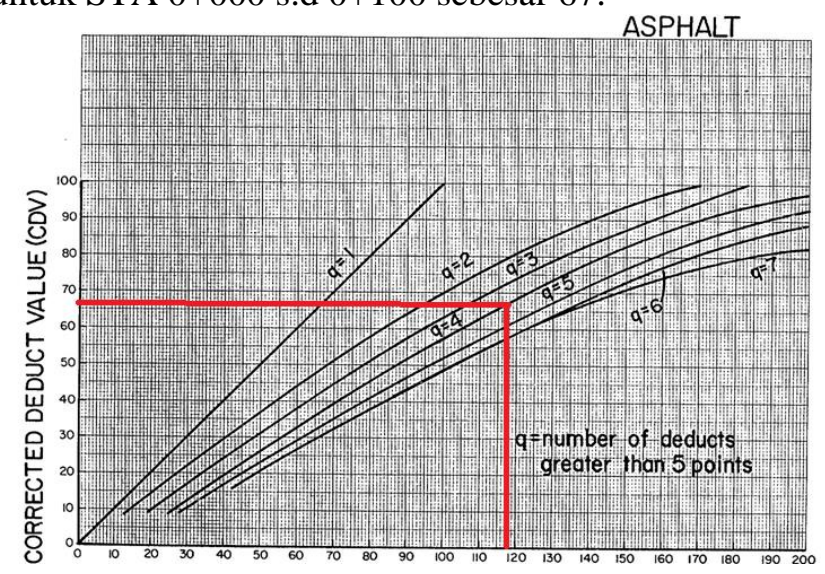

Gambar 3. Grafik Corrected Deduct Value (CDV)

Sumber : Analisis, 2020 
g. Menghitung nilai kondisi Perkerasan

Nilai kondisi diperoleh dengan mengurangi 100 dengan nilai CDV yang diperoleh. Rumus sebagai berikut :
PCI $=100-\mathrm{CDV}$, dimana:
PCI = Nilai kondisi perkerasan
$\mathrm{CDV} \quad=$ Nilai pengurangan terkoreksi

Nilai yang diperoleh tersebut dapat menunjukan kondisi perkerasan pada setiap segmen yang diamati dengan menggunakan parameter PCI. Untuk STA 0+000 s.d 0+100 nilai CDV yang didapat yaitu 67 maka PCI $=100-67=33$, maka jalan tersebut berada pada parameter BURUK (Poor).

Tabel 8. Rekapitulasi Nilai Kerusakan PCI

\begin{tabular}{|c|c|c|c|c|c|c|}
\hline No & STA & TDV & $\mathbf{q}$ & CDV & 100-CDV & PCI \\
\hline 1 & $0+000-0+100$ & 117 & 4 & 67 & 33 & Buruk \\
\hline 2 & $0+100-0+200$ & 110 & 2 & 75 & 25 & Buruk \\
\hline 3 & $0+200-0+300$ & 157 & 4 & 87 & 13 & Sangat Buruk \\
\hline 4 & $0+300-0+400$ & 108 & 6 & 53 & 47 & Sedang \\
\hline 5 & $0+400-0+500$ & 140 & 5 & 72 & 28 & Buruk \\
\hline 6 & $0+500-0+600$ & 113 & 4 & 65 & 35 & Buruk \\
\hline 7 & $0+600-0+700$ & 67 & 3 & 43 & 57 & Baik \\
\hline 8 & $0+700-0+800$ & 101 & 3 & 64 & 36 & Buruk \\
\hline 9 & $0+800-0+900$ & 119 & 4 & 68 & 32 & Buruk \\
\hline 10 & $0+900-1+000$ & 135 & 4 & 76 & 24 & Sangat Buruk \\
\hline 11 & $1+000-1+100$ & 154 & 2 & 95 & 5 & Gagal \\
\hline 12 & $1+100-1+200$ & 66 & 2 & 48 & 52 & Sedang \\
\hline 13 & $1+200-1+300$ & 142 & 4 & 80 & 20 & Sangat Buruk \\
\hline 14 & $1+300-1+400$ & 20 & 1 & 20 & 80 & Sangat Baik \\
\hline 15 & $1+400-1+500$ & 25 & 1 & 25 & 75 & Sangat Baik \\
\hline 16 & $1+500-1+600$ & 14 & 1 & 14 & 86 & Sempurna \\
\hline 17 & $1+600-1+700$ & 2 & 0 & 0 & 100 & Sempurna \\
\hline 18 & $1+700-1+800$ & 54 & 1 & 54 & 46 & Sedang \\
\hline 19 & $1+800-1+900$ & 54 & 1 & 54 & 46 & Sedang \\
\hline 20 & $1+900-2+000$ & 61 & 2 & 45 & 55 & Sedang \\
\hline \multicolumn{5}{|c|}{ TOTAL PCI } & 895 & \\
\hline \multicolumn{5}{|c|}{ RATA - RATA PCI } & 44.75 & Sedang \\
\hline
\end{tabular}

Sumber: Analisis, 2020

Dari table 8 diatas, didapatkan Nilai rata-rata PCI keseluruhan jalan sebesar 44.75. Artinya, kondisi permukaan jalan dalam kondisi Sedang (Fair). Nilai PCI tertinggi terdapat pada STA 1+600 s.d 1+700 dengan nilai PCI 100 termasuk dalam kategori Sempurna (Excelent), sedangkan Nilai PCI terendah terdapat pada STA $1+000$ s.d 1+100 dengan nilai PCI 5 termasuk dalam kategori Gagal (Failed).

B. Metode SDI (Surface Distress Index)

1. Membuat Tabel Survei Kersakan Jalan 
Tabel 9 : Data kondisi dan Hasil Pengukuran Ruas Jalan Raya

Jakarta Km.4 Kota Serang

\begin{tabular}{|c|c|c|c|c|c|}
\hline \multicolumn{6}{|c|}{ Nama Survey :Survei Kondisi Kerusakan Jalan } \\
\hline Lokasi & \multicolumn{5}{|c|}{ :Ruas Jalan Raya Jakarta Km.4 Kota Serang } \\
\hline Cuaca & \multirow{2}{*}{\multicolumn{2}{|c|}{$\begin{array}{l}: \text { Cerah } \\
\text { : Team }\end{array}$}} & \multicolumn{2}{|c|}{ Panjang } & $: 2000 \mathrm{~m}$ \\
\hline Surveyor & & & \multicolumn{2}{|c|}{ Lebar } & $: 7 \mathrm{~m}$ \\
\hline \multirow{2}{*}{ STA } & \multirow{2}{*}{$\begin{array}{c}\text { Kelas } \\
\text { Kerusakan }\end{array}$} & \multicolumn{3}{|c|}{ Ukuran } & \multirow{2}{*}{ Jenis Kerusakan } \\
\hline & & $\mathrm{P}(\mathrm{m})$ & $\mathrm{L}(\mathrm{m})$ & $\mathrm{h}(\mathrm{m})$ & \\
\hline \multirow{10}{*}{$\begin{array}{c}0+500- \\
0+600\end{array}$} & $\mathrm{M}$ & 70 & 0.8 & \multirow[t]{10}{*}{0.023} & Alur \\
\hline & M & 2.5 & 0.5 & & Tambalan \\
\hline & M & 2 & 0.3 & & Tambalan \\
\hline & $\mathrm{L}$ & 2.9 & 0.4 & & Tambalan \\
\hline & $\mathrm{L}$ & 2.6 & 0.2 & & Tambalan \\
\hline & M & 5 & 0.8 & & Amblas \\
\hline & M & 4 & 0.3 & & Kegemukan \\
\hline & $\mathrm{H}$ & 0.9 & 1.1 & & Lubang \\
\hline & $\mathrm{L}$ & 3 & 0.05 & & Retak Melintang \\
\hline & $\mathrm{L}$ & 3 & 0.05 & & Retak Melintang \\
\hline
\end{tabular}

Sumber : Survey, 2020

2. Membagi menjadi beberapa segmen berjarrak 100 meter. Memasukan jenis dan tingkat kerusakan serta jumlah titik dan luasan kerusakan pada tiap jarak 100 meter per segmen dari total panjang 2000 meter. Dari pembagian persegmen, didapat totalnya yaitu 20 segmen pada Ruas Jalan Raya Jakarta Km.4 Kota Serang.

3. Menetapkan $\mathrm{SDI}_{1}$ berdasarkan luas retak . Pada STA 0+500 s.d 0+600 persentase retak yang didapat yaitu sebesar $0.04 \%$ sehingga masuk kategori $<10 \%$ dan mendapatkan nilai SDI 10.

4. Menetapkan $\mathrm{SDI}_{2}$ berdasarkan lebar rata-rata retak. Pada STA 0+500 s.d 0+600 jumlah lubang yang didapat yaitu sebanyak $5 \mathrm{~mm}$ sehingga masuk kategori lebar $>3 \mathrm{~mm}$ dan mendapatkan nilai $\mathrm{SDI}_{2}=$ $\mathrm{SDI}_{1} \times 2=10$

5. Menetukan $\mathrm{SDI}_{3}$ berdasarkan jumlah lubang. Pada STA 0+500 s.d 0+600 Lebar rata-rata retak yang didapat yaitu sebesar 1 buah sehingga masuk kategori $<1 / 100 \mathrm{~m}$ dan mendapatkan nilai $\mathrm{SDI}_{3}=\mathrm{SDI}_{2}$ $+15=25$.

6. Menetapkan $\mathrm{SDI}_{4}$ berdasarkan kedalaman bekas roda. Pada STA 0+500 s.d 0+600 kedalaman bekas roda yang didapat yaitu sebesar $2.3 \mathrm{~cm}$ sehingga masuk kategori $1-3 \mathrm{~cm}$ dalam dan mendapatkan nilai $\mathrm{SDI}_{4}=\mathrm{SDI}_{3}+(5 \times 2)=35$. Nilai yang diperoleh tersebut dapat menunjukan kondisi perkerasan pada setiap segmen yang diamati dengan menggunakan parameter SDI. Untuk STA 0+500 s.d 0+600 nilai SDI yang didapat yaitu 35, maka jalan tersebut berada pada parameter BAIK.

Tabel 10. Rekapitulasi Nilai Kerusakan SDI

\begin{tabular}{cccl}
\hline No & STA & Nilai SDI & \multicolumn{1}{c}{ Kondisi } \\
\hline 1 & $0+000-0+100$ & 80 & Sedang \\
2 & $0+100-0+200$ & 75 & Sedang \\
3 & $0+200-0+300$ & 85 & Sedang \\
4 & $0+300-0+400$ & 10 & Baik \\
5 & $0+400-0+500$ & 85 & Sedang \\
6 & $0+500-0+600$ & 35 & Baik \\
7 & $0+600-0+700$ & 25 & Baik \\
8 & $0+700-0+800$ & 85 & Sedang \\
9 & $0+800-0+900$ & 85 & Sedang
\end{tabular}




\begin{tabular}{cccl}
10 & $0+900-1+000$ & 85 & Sedang \\
11 & $1+000-1+100$ & 245 & Rusak Berat \\
12 & $1+100-1+200$ & 25 & Baik \\
13 & $1+200-1+300$ & 95 & Sedang \\
14 & $1+300-1+400$ & 20 & Baik \\
15 & $1+400-1+500$ & 15 & Baik \\
16 & $1+500-1+600$ & 0 & Baik \\
17 & $1+600-1+700$ & 0 & Baik \\
18 & $1+700-1+800$ & 10 & Baik \\
19 & $1+800-1+900$ & 10 & Baik \\
20 & $1+900-2+000$ & 25 & Baik \\
Total Nilai SDI & 1095 & \\
Rata - Rata SDI & 54.75 & Sedang \\
\hline
\end{tabular}

Sumber : Analisis , 2020

a. Nilai rata-rata SDI keseluruhan yang ditampilkan oleh Tabel 10 diatas, adalah sebesar 54.75. Artinya, kondisi permukaan jalan dalam kondisi Sedang. Nilai SDI tertinggi terdapat pada STA $1+500$ s.d 1+600 dan STA 1+600 s.d 1+700 dengan nilai SDI 0 termasuk dalam kategori Baik, sedangkan Nilai SDI terendah terdapat pada STA 1+000 s.d 1+100 dengan nilai SDI 245 termasuk dalam kategori Rusak Berat.

Berikut ini ditampilkan grafik Nilai Kerusakan Jalan sesuai hasil penggunaan Metode PCi dan SDI.

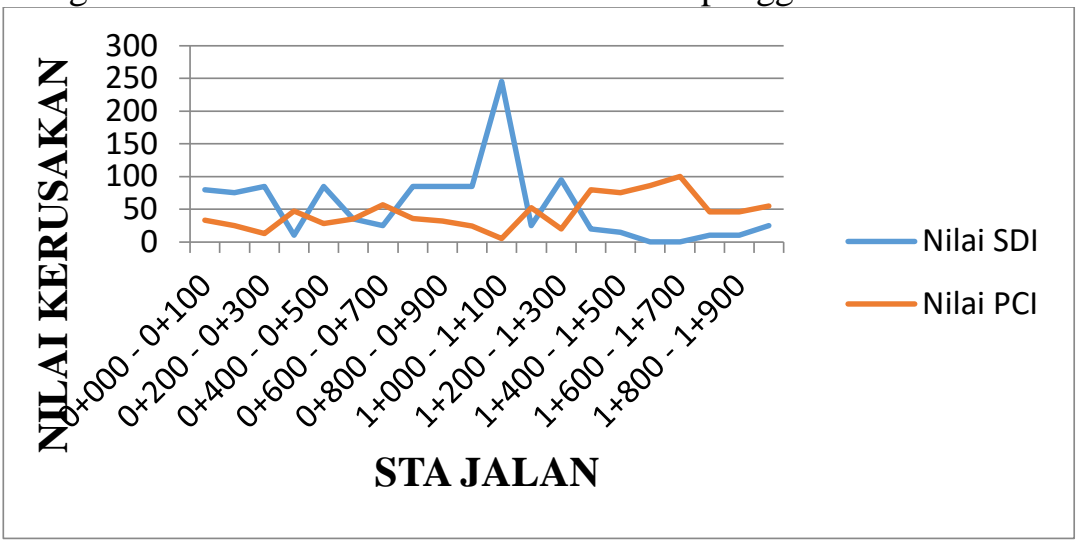

Gambar 4 Grafik Nilai Kerusakan PCI dan SDI

Alternatif penanganan kerusakan jalan mengacu pada Pedoman Surface Distress Index yaitu manual Perbaikan Standar Untuk Pemeliharaan Rutin Jalan No.001-02/M/MB/2011. Berdasarkan jenis kerusakan jalan yang didapat adalah sebagai berikut :

Tabel 11 Rekapitulasi Alternatif Penanganan Kerusakan Raya Jakarta Km.04 Kota Serang per 100 meter

\begin{tabular}{lcll}
\hline No & \multicolumn{1}{c}{ STA } & \multicolumn{1}{c}{ Jenis Kerusakan } & \multicolumn{1}{c}{ Metode Perbaikan } \\
\hline & & Lubang & P1 (Penebaran Pasir) \\
& & Retak Pinggir & P2 (Pengaspalan) \\
1 & \multirow{2}{*}{$0+000-0+100$} & Retak Kulit Buaya & P3 (Penutupan Retak) \\
& & Kegemukan & P4 (Pengisisan Retak) \\
& & Amblas & P5 (Penambalan Lubang) \\
& & & P6 (Perataan) \\
\hline \multirow{2}{*}{2} & \multirow{2}{*}{$0+100-0+200$} & Lubang & P5 (Penambalan Lubang) \\
& & Amblas & P6 (Perataan) \\
\hline 3 & $0+200-0+300$ & Lubang & P2 (Pengaspalan) \\
\hline
\end{tabular}




\begin{tabular}{|c|c|c|c|}
\hline & & $\begin{array}{l}\text { Amblas } \\
\text { Alur } \\
\text { Retak Pinggir } \\
\text { Retak Memanjang }\end{array}$ & $\begin{array}{l}\text { P3 (Penutupan Retak) } \\
\text { P4 (Pengisisan Retak) } \\
\text { P5 (Penambalan Lubang) } \\
\text { P6 (Perataan) }\end{array}$ \\
\hline 4 & $0+300-0+400$ & $\begin{array}{l}\text { Kegemukan } \\
\text { Tambalan } \\
\text { Alur } \\
\text { Amblas } \\
\text { Retak Memanjang } \\
\text { Retak Kulit Buaya }\end{array}$ & $\begin{array}{l}\text { P1 (Penebaran Pasir) } \\
\text { P2 (Pengaspalan) } \\
\text { P3 (Penutupan Retak) } \\
\text { P4 (Pengisisan Retak) } \\
\text { P5 (Penambalan Lubang) } \\
\text { P6 (Perataan) }\end{array}$ \\
\hline 5 & $0+400-0+500$ & $\begin{array}{l}\text { Alur } \\
\text { Kegemukan } \\
\text { Amblas } \\
\text { Tambalan } \\
\text { Lubang } \\
\end{array}$ & $\begin{array}{l}\text { P1 (Penebaran Pasir) } \\
\text { P5 (Penambalan Lubang) } \\
\text { P6 (Perataan) }\end{array}$ \\
\hline 6 & $0+500-0+600$ & $\begin{array}{l}\text { Alur } \\
\text { Tambalan } \\
\text { Amblas } \\
\text { Kegemukan } \\
\text { Lubang } \\
\text { Retak Melintang }\end{array}$ & $\begin{array}{l}\text { P1 (Penebaran Pasir) } \\
\text { P2 (Pengaspalan) } \\
\text { P3 (Penutupan Retak) } \\
\text { P4 (Pengisisan Retak) } \\
\text { P5 (Penambalan Lubang) } \\
\text { P6 (Perataan) }\end{array}$ \\
\hline 7 & $0+600-0+700$ & $\begin{array}{l}\text { Amblas } \\
\text { Lubang } \\
\text { Retak Kulit Buaya } \\
\text { Tambalan } \\
\text { Retak Melintang } \\
\text { Kegemukan } \\
\end{array}$ & $\begin{array}{l}\text { P1 (Penebaran Pasir) } \\
\text { P2 (Pengaspalan) } \\
\text { P3 (Penutupan Retak) } \\
\text { P4 (Pengisisan Retak) } \\
\text { P5 (Penambalan Lubang) } \\
\text { P6 (Perataan) }\end{array}$ \\
\hline 9 & $0+800-0+900$ & $\begin{array}{l}\text { Tambalan } \\
\text { Lubang } \\
\text { Amblas } \\
\text { Kegemukan } \\
\text { Alur } \\
\end{array}$ & $\begin{array}{l}\text { P1 (Penebaran Pasir) } \\
\text { P5 (Penambalan Lubang) } \\
\text { P6 (Perataan) }\end{array}$ \\
\hline 10 & $0+900-1+000$ & $\begin{array}{l}\text { Kegemukan } \\
\text { Alur } \\
\text { Amblas } \\
\text { Tambalan } \\
\text { Lubang }\end{array}$ & $\begin{array}{l}\text { P1 (Penebaran Pasir) } \\
\text { P5 (Penambalan Lubang) } \\
\text { P6 (Perataan) }\end{array}$ \\
\hline 11 & $1+000-1+100$ & $\begin{array}{l}\text { Lubang } \\
\text { Alur } \\
\text { Retak Melintang }\end{array}$ & $\begin{array}{l}\text { P2 (Pengaspalan) } \\
\text { P3 (Penutupan Retak) } \\
\text { P4 (Pengisisan Retak) } \\
\text { P5 (Penambalan Lubang) } \\
\text { P6 (Perataan) }\end{array}$ \\
\hline 12 & $1+100-1+200$ & $\begin{array}{l}\text { Alur } \\
\text { Lubang }\end{array}$ & $\begin{array}{l}\text { P5 (Penambalan Lubang) } \\
\text { P6 (Perataan) }\end{array}$ \\
\hline 13 & $1+200-1+300$ & $\begin{array}{l}\text { Lubang } \\
\text { Tambalan } \\
\text { Alur } \\
\text { Retak Melintang }\end{array}$ & $\begin{array}{l}\text { P2 (Pengaspalan) } \\
\text { P3 (Penutupan Retak) } \\
\text { P4 (Pengisisan Retak) } \\
\text { P5 (Penambalan Lubang) } \\
\text { P6 (Perataan) }\end{array}$ \\
\hline 14 & $1+300-1+400$ & $\begin{array}{l}\text { Alur } \\
\text { Tambalan }\end{array}$ & $\begin{array}{l}\text { P2 (Pengaspalan) } \\
\text { P3 (Penutupan Retak) }\end{array}$ \\
\hline
\end{tabular}




\begin{tabular}{|c|c|c|c|}
\hline & & $\begin{array}{l}\text { Retak Memanjang } \\
\text { Amblas }\end{array}$ & $\begin{array}{l}\text { P4 (Pengisisan Retak) } \\
\text { P5 (Penambalan Lubang) } \\
\text { P6 (Perataan) }\end{array}$ \\
\hline 15 & $1+400-1+500$ & $\begin{array}{l}\text { Lubang } \\
\text { Kegemukan } \\
\text { Amblas }\end{array}$ & $\begin{array}{l}\text { P1 (Penebaran Pasir) } \\
\text { P5 (Penambalan Lubang) } \\
\text { P6 (Perataan) }\end{array}$ \\
\hline 16 & $1+500-1+600$ & Tambalan & P6 (Perataan) \\
\hline 17 & $1+600-1+700$ & Kegemukan & P1 (Penebaran Pasir) \\
\hline 18 & $1+700-1+800$ & Alur & $\begin{array}{l}\text { P5 (Penambalan Lubang) } \\
\text { P6 (Perataan) }\end{array}$ \\
\hline 19 & $1+800-1+900$ & Alur & $\begin{array}{l}\text { P5 (Penambalan Lubang) } \\
\text { P6 (Perataan) }\end{array}$ \\
\hline 20 & $1+900-2+000$ & $\begin{array}{l}\text { Alur } \\
\text { Kegemukan } \\
\text { Lubang }\end{array}$ & $\begin{array}{l}\text { P1 (Penebaran Pasir) } \\
\text { P6 (Perataan) } \\
\text { P5 (Penambalan Lubang) }\end{array}$ \\
\hline
\end{tabular}

\section{KESIMPULAN}

Berdasarkan analisis data yang sudah dilakukan, dapat diambil beberapa kesimpulan bahwa nilai tingkat kerusakan pada ruas jalan raya Jakarta Km.4 Kota serang - Banten sepanjang 2000 meter sebagai berikut:

1. Metode PCI (Pavement Condition Index)

a. Nilai rata-rata PCI keseluruhan jalan sebesar 44.75. Nilai PCI tersebut menunjukan kondisi permukaan jalan dalam kondisi Sedang (Fair)

b. Nilai PCI tertinggi terdapat pada STA 1+600 s.d 1+700 dengan nilai PCI 100 termasuk dalam kategori Sempurna (Excelent), sedangkan Nilai PCI terendah terdapat pada STA 1+000 s.d 1+100 dengan nilai PCI 5 termasuk dalam kategori Gagal (Failed).

2. Metode SDI (Surface Condition Index)

b. Nilai rata-rata SDI keseluruhan jalan sebesar 54.75. Nilai SDI tersebut menunjukan kondisi permukaan jalan dalam kondisi Sedang.

c. Nilai SDI tertinggi terdapat pada STA $1+500$ s.d 1+600 dan STA 1+600 s.d 1+700 dengan nilai SDI 0 termasuk dalam kategori Baik, sedangkan Nilai SDI terendah terdapat pada STA 1+000 s.d 1+100 dengan nilai SDI 245 termasuk dalam kategori Rusak Berat.

3. Alternatif penanganan kerusakan jalan menurut metode PCI jenis Pemeliharaan Tambalan dan Lapis tambahan, sedangkan menurut metode SDI adalah Pemeliharaan rutin.

\section{DAFTAR PUSTAKA}

Ari Sanjaya, Yudi dkk. 2017. Evaluasi Tingkat Kerusakan Permukaan Jalan Untuk Menentukan Jenis Perancangan Dengan Sistem Penilaian Menurut Surface Distress Index (Studi Kasus Jalan Nasional Bireuen-Bts. Kota Lhokseumawe, Kecamatan Krueng Geukueh mulai Sta 253+000 s/d Sta 257+000) . Lhokseumawe (Jurnal - Politeknik Negeri Lhokseumawe) Vol. 1 No. 01.

Baihaqi dkk. 2018. Tinjauan Kondisi Perkerasan Jalan Dengan Kombinasi Nilai International Roughness Index (IRI) dan Surface Distress Index(SDI) Pada Jalan Takengon - Blangkejeren, Banda Aceh (Jurnal - Universitas Syiah Kuala). DOI: https://doi.org/10.24815/jts.v1i3.9993.

Direktorat Jendral Bina Marga. 2011. Indonesia Integrated Road Management System(IIRMS). No. SMD03/RC, Panduan Survei Kondisi Jalan, Kementrian Pekerjaan Umum, Pedoman - Surface Distress Index.

Direktorat Jenderal Surface Distress Index. 2011, Manual Konstruksi dan Bangunan. No. 001-01/M/BM/2011, Survei Kondisi Jalan untuk Pemeliharaan Rutin, Kementerian Pekerjaan Umum, Direktorat Jenderal Surface Distress Index. Direktorat (Pedoman - Surface Distress Index)

Hadiyatmo, Hary Christady. 2015. Pemeliharaan Jalan Raya. Yogyakarta: Gadjah Mada University Press (Buku) 
Menteri Pekerjaan Umum Republik Indonesi. 2012. No: 03/PRT/M/2012. Tentang Pedoman Penetapan Fungsi Jalan dan Status Jalan.

Silvia Sukirman. 1999. Perkerasan Lentur Jalan Raya. Bandung.

Yahya, Rafiko dkk. 2019. Analisa kerusakan jalan menggunakan metode Pavement Condition Iindex (PCI) dan Surface Condition Index (SDI). Conference on Innovation and Application of Science and Technology (CIASTECH 2019) Universitas Widyagama Malang, 02 Oktober 2019. 